\title{
Antibacterial activity of leaves and fruits extract of Tamarindus indica against clinical isolates of Escherichia coli and Shigella at potiskum yobe state, Nigeria
}

\begin{abstract}
The study was conducted to determine the phytochemical composition and antibacterial activity of Tamarindus indica leaves and fruits extracts against clinical isolates of Escherichia coli and Shigella sp isolated from stool samples of pregnant women attending antenatal clinic Potiskum, Yobe State, Nigeria. Preliminary phytochemical analysis was conducted using laboratory method while agar well diffusion method was used to determine antibacterial activity of the extracts. The result of phytochemical screening of the extracts showed the presence of alkaloid, glycoside, saponin, tannin, anthraquinone and steroid, reducing sugar flavonoid, terpenoid and phenol. The result of the antibacterial efficacy of the extracts against the isolates indicated the extracts were active against the isolates with higher activity in methanol extract (with average zone of inhibition of $14.48 \mathrm{~mm}$ ) when compared to aqueous extract $(12.52 \mathrm{~mm})$. The result of susceptibility of the isolates to the extracts showed Escherichia coli is more sensitive to the extract with average zone of inhibition of $14.62 \mathrm{~mm}$ when compared to Shigella sp with average zone of inhibition of $11.47 \mathrm{~mm}$. The minimum inhibitory concentration (MIC) of the extracts showed that dilutions of various concentrations of aqueous and methanol extracts inhibit the growth of the isolates at a concentration of between $3.125-25 \mathrm{mg} / \mathrm{ml}$. Statistical analysis of the results indicated that there is significant different in the activity of the extracts against the isolates used at $\mathrm{p}<0.05$. Findings from this work support the use of Tamarindus indica leaves and fruits extracts for medicinal purpose.
\end{abstract}

Keywords: antibacterial activity, Escherichia coli, extract, Shigella, tamarinds
Volume 7 Issue 5 - 2018

\author{
Abdallah MS,' Muhammad Ali² \\ 'Desert Research Monitoring and Control centre, Yobe State \\ University Damaturu, Nigeria \\ ${ }^{2}$ Department of Microbiology, Federal University Gusau, Nigeria
}

Correspondence: Muhammad Ali Department of Microbiology, Federal University Gusau, Nigeria, Email alimahd4real@gmail.com

Received: September 28, 2018 | Published: October 25, 2018

\section{Introduction}

Herbs have been used as medicine since the history of man and herbal preparation have been a major component of all traditional medicine system particularly in Asia, south America and Africa. ${ }^{1}$ Nevertheless, herbal medicine was the starting point for the western medicine before the latter greatly diversified. An estimate of 75$90 \%$ of rural population of the world still relies on herbs for their healthcare. Thus, in many village market places in Asia, Africa and Latin America, medicinal herbs are sold alone side vegetable and other wares. ${ }^{2}$ However even in the western culture where herbal medicine seemed to have been forgotten for a long time in preference to synthetic drugs, there is a rethinking and resurgence of herbal remedies. The new direction has been necessitated by high rate of resistance to antibacterial drugs. ${ }^{3}$

Medicinal plants materials are considered safe and understandable so because most of them are known as metabolize human and animal food items. Several Nigerians, used plant for treatment of disease have been authenticated to have antibacterial activity using in vitro test method. ${ }^{4}$ Moreover, Tamarindus indica (tamarind) belong to the dicotyledonous family Leguminosae and sub-family Caesalpiniceae. ${ }^{5}$ Tamarind has been used for centuries as a medicine plant; it fruits are most valuable part which have often been reported as curative in several pharmacopoeias, the leaves have a proven hap to protective activity associated with the presence of polydroxylated compound with many of them of a flavonoid nature. ${ }^{6}$ Leaves also present good level of protein, fat, fibber, and some vitamin such as thiamine, riboflavin, niacin, ascorbic acid and B-carotene. ${ }^{?}$
Flavonoids and polyphenols the metabolites found in leaves have recorded as antimicrobial agents in many other plants. Many studies have shown the antimicrobial activity of tamarind leaves against gram positive and negative bacteria. In Northern Nigeria, the fresh stem bark and fresh leaves are used as decoction mixed with potash for the treatment of stomach disorder, general body pain, jaundice, yellow fever and as blood tonic and skin cleanser. ${ }^{8}$ The study was aimed to investigate the phytochemical and antimicrobial activity of the leaves and fruit extracts of Tamarindus indica against clinical isolates of Escherichia coli and Shigella sp isolated from stool samples of pregnant women attending antenatal clinic Potiskum, Yobe State, Nigeria.

\section{Materials and methods}

\section{Ethical approval}

Ethical approval for the study was obtained from Ministry of health Damaturu, Yobe State based on the consent of the Potiskum hospital Ethical Committee.

\section{Isolation and identification of test isolates}

Two (2) bacterial isolates recovered from stool samples of pregnant women attending antenatal clinic Potiskum, Yobe State, Nigeria namely; Shigella $s p$ and Escherichia coli were used in this study. The bacteria isolates were characterized to species level by using different laboratory procedures including; Gram's stain, cultural characterization (Nutrient and MacConkey agar) and Biochemical tests include (Indole, Methyl red, Voges Proskauer, motility and 
Citrate utilization) as described by Holt et al., ${ }^{9}$ Cheesbrough. ${ }^{10}$ The isolates were maintained on Nutrient agar slants at $4^{0} \mathrm{C}$.

\section{Collection and identification of plant materials}

Tamarindus indica leaves and fruits were used in this study, which was collected from Yobe State University, Damaturu. Botanical identification and authentication of the plant material was done at Botanical garden in the Department of Biological Sciences, Yobe State University Damaturu. Voucher specimens were deposited there for future reference. The leaves and fruits were washed with water and removed dust and rinsed with distilled water, air dried for twoweeks and pulverized into powder form using sterile mortar and pestle under laboratory as described by Ali et al. ${ }^{11}$ The powder samples were bagged in a black polythene bag and stored in air tight container for further work.

\section{Preparation of leaves and fruits extracts}

Approximately fifty (50) gram each of powered leaves and fruits were each macerated in $500 \mathrm{ml}$ of distilled water and methanol respectively for period of 24 hour at room temperature as described by Okoli et al. ${ }^{12}$ Each preparation was filtered through a Whatman filter paper and the aqueous filtrate was evaporated to dryness in water bath at $40^{\circ} \mathrm{C}$ while methanol extract in rotary evaporator at $50^{\circ} \mathrm{C}$. The residue obtained was further diluted using 10\% Dimethylsulphoxide (DMSO) to produce $100 \mathrm{mg} / \mathrm{ml}$ of the extract from which various concentrations of $50,40,30,20$ and $10 \mathrm{mg} / \mathrm{ml}$ were produced. ${ }^{13}$

\section{Phytochemical screening}

Qualitative method of screening was carried out so as to test the presence of the present bioactive ingredients, as being adopted by Kumar et al. ${ }^{14}$ The presence or absence of the following phytochemicals was determined; Alkaloid, saponin, glycoside, reducing sugar, flavonoid, steroid, phenol, terpenoid, tannin and anthraquinone.

\section{Antibacterial activity of the extracts}

The sensitivity of each extracts was determined using the agar well diffusion method as described by Ahmed and $\mathrm{Beg}^{15}$ with modifications. The prepared bacterial suspension equivalent to $0.5 \mathrm{Mc}$ Farland Standard $\left(1.5 \times 10^{6} \mathrm{CFU}\right)$ was inoculated into sterile MuellerHinton agar medium in a sterile Petri-dish and rotated at $60^{\circ}$ to ensure and even distribution of the inoculums. A sterile $6 \mathrm{~mm}$ diameter sterile cork borer was used to bore 6 wells into the agar medium. The wells were then filled up with approximately $0.1 \mathrm{ml}$ of the extract solution at a concentration of $10,20,30,40$ and $50 \mathrm{mg} / \mathrm{ml}$ taking care to prevent spillage onto the surface of the agar medium. The plates were rotated allowed to stand on the laboratory bench for 1 hour to allow proper diffusion of the extract into the medium after which the plates were incubated at $37^{\circ} \mathrm{C}$ for 24 hours, and thereafter the plates were observed for zones of inhibition and measured. The experiment was conducted in triplicate and the average values were recorded. Ciprofloxacin $50 \mathrm{mg} / \mathrm{ml}$ (Micro Lab limited) was served as a control (positive) for the experiment.

\section{Determination of minimum inhibitory concentration (MIC)}

The minimum inhibitory concentration MIC of the extracts was determined using broth dilution technique. Double fold serial dilutions of the extracts were prepared by adding $2 \mathrm{ml}$ of $100 \mathrm{mg} / \mathrm{ml}$ of the extract into a test tube containing $2 \mathrm{ml}$ of Nutrient broth, thus producing solution containing $50 \mathrm{mg} / \mathrm{ml}$ of the extract. The process continue serially up to test tube No. 5 , hence producing the following concentrations; 50, 25, 12.5, $6.253 .125 \mathrm{mg} / \mathrm{ml}$. Test tube No. 6 do not contain extracts and serve as negative control. Exactly $0.5 \mathrm{ml}$ of $0.5 \mathrm{McF}$ arland equivalent standards of test organisms were introduced into the test tubes and incubated at $37^{\circ} \mathrm{C}$ for 24 hours. After incubation the test tubes were observed for growth by checking for turbidity. ${ }^{15}$

\section{Statistical analysis}

The data of average zone of inhibition produced by the isolates against the extracts used were analyzed using One-Way ANOVAs from statistical program SPSS 21.0 (Statistical Package for the Social Sciences). The results were presented as the means \pm standard deviation. Significance level for the differences was set at $\mathrm{p}<0.05$.

\section{Results}

\section{Identification of the isolates}

The morphological and biochemical characterization of the isolates is presented in Table 1. Both the isolates are Gram negative rods, negative for Voges Proskauer and citrate utilization test while both positive for methyl-red test. E. coli is motile and lactose fermenter while Shigella is non motile and non-lactose fermenter.

Table I Morphological and biochemical tests for identification of the isolates Key: +, positive; -, negative

\begin{tabular}{|c|c|c|c|}
\hline $\mathbf{S} / \mathbf{N}$ & $\begin{array}{l}\text { Agarl } \\
\text { Biochemical } \\
\text { test }\end{array}$ & Escherichia coli & Shigella sp \\
\hline I & Nutrient agar & $\begin{array}{l}\text { Whitish moist, } \\
\text { smooth surface and } \\
\text { opaque colony. }\end{array}$ & $\begin{array}{l}\text { Translucent, opaque and } \\
\text { glistening colony. }\end{array}$ \\
\hline 2 & MacConkey agar & $\begin{array}{l}\text { Non-mucoid dark } \\
\text { pinkish colony }\end{array}$ & $\begin{array}{l}\text { Transparent colourless } \\
\text { colony with jagged edge }\end{array}$ \\
\hline 3 & $\begin{array}{l}\text { Gram staining/ } \\
\text { shape }\end{array}$ & Negative/rod & Negative/rod \\
\hline 4 & Indole test & + & - \\
\hline 5 & Methyl-red test & + & + \\
\hline 6 & $\begin{array}{l}\text { Voges Proskauer } \\
\text { test }\end{array}$ & - & - \\
\hline 7 & $\begin{array}{l}\text { Citrate utilization } \\
\text { test }\end{array}$ & - & - \\
\hline 8 & Motility test & Motile & Non-motile \\
\hline
\end{tabular}

\section{Phytochemical screening}

The phytochemical constituent of leaves and fruits extracts of Tamarindus indica is presented in Table 2. The preliminary phytochemical screening of the extracts revealed the presence of Alkaloid, saponin, glycoside, reducing sugar, flavonoid, steroid, phenol, terpenoid, tannin and anthraquinone. More phyto-constituents found in the fruits than the leaves extracts.

\section{Antibacterial activity of the leaves extracts}

The antibacterial activity of Tamarindus indica leaves extracts against Escherichia coli and Shigella sp is presented in Table 3. The result showed that methanol extract is more effective with average zone of inhibition of $13.85 \mathrm{~mm}$ than aqueous extract with average zone of inhibition of $9.57 \mathrm{~mm}$. Based on the result, Escherichia coli is more sensitive to the extract than Shigella sp. The zone of inhibition shown by Ciprofloxacin $(25 \mathrm{mg} / \mathrm{ml})$ is 23 and $21 \mathrm{~mm}$ for Escherichia coli and Shigella sp respectively. 
Table 2 Phytochemical Screening of the plant materials Key: +, presence of phytochemical; -, absent of phytochemical

\begin{tabular}{llll}
\hline S/N & Phytochemical & Leaves extract & Fruits extracts \\
\hline 1 & Alkaloids & + & + \\
2 & Saponin & + & + \\
3 & Glycosides & - & + \\
4 & Reducing sugar & - & + \\
5 & Flavonoid & + & + \\
6 & Steroids & + & + \\
7 & Phenols & + & + \\
8 & Terpenoid & + & - \\
9 & Tannin & + & + \\
10 & Anthraquinone & + & +
\end{tabular}

Table 3 Antibacterial activity of the leaves extracts against the isolates Key: ALE, aqueous leaves extract; MLE, methanol leaves extract. Values having different superscript in the same row are considered significantly different at probability level of $p<0.05$.

\begin{tabular}{llll}
\hline Extracts & Conc. $(\mathrm{mg} / \mathrm{ml})$ & Escherichia coli & Shigella sp \\
\hline \multirow{4}{*}{ ALE } & 10 & $05.34 \pm 0.3^{\mathrm{b}}$ & $00.00 \pm 0.0^{\mathrm{a}}$ \\
& 20 & $09.00 \pm 0.0^{\mathrm{b}}$ & $00.00 \pm 00^{\mathrm{a}}$ \\
& 30 & $12.67 \pm 1.2^{\mathrm{b}}$ & $07.34 \pm 0.8^{\mathrm{a}}$ \\
& 40 & $13.34 \pm 1.1^{\mathrm{a}}$ & $11.34 \pm 0.2^{\mathrm{a}}$ \\
& 50 & $17.00 \pm 1.8^{\mathrm{b}}$ & $13.67 \pm 1.3^{\mathrm{a}}$ \\
& 10 & $09.34 \pm 0.4^{\mathrm{a}}$ & $08.00 \pm 1.1^{\mathrm{b}}$ \\
& 20 & $10.67 \pm 0.5^{\mathrm{a}}$ & $09.67 \pm 0.4^{\mathrm{a}}$ \\
& 30 & $13.67 \pm 0.7^{\mathrm{a}}$ & $13.67 \pm 0.9^{\mathrm{a}}$ \\
& 40 & $18.00 \pm 1.1^{\mathrm{a}}$ & $16.67 \pm 1.2^{\mathrm{a}}$ \\
& 50 & $21.00 \pm 1.3^{\mathrm{b}}$ & $17.34 \pm 1.8^{\mathrm{a}}$ \\
& 25 & $23.34 \pm 1.3^{2}$ & $21.00 \pm 0.0$ \\
\hline
\end{tabular}

Table 4 Antibacterial activity of the fruits extracts against the isolates Key: AFE, aqueous fruits extract; MFE, methanol fruits extract. Values having different superscript in the same row are considered significantly different at probability level of $p<0.05$.

\begin{tabular}{llll}
\hline Extracts & Conc. $(\mathrm{mg} / \mathrm{ml})$ & Escherichia coli & Shigella sp \\
\hline & 10 & $08.34 \pm 0.1^{\mathrm{a}}$ & $07.67 \pm 0.0^{\mathrm{a}}$ \\
AFE & 20 & $13.34 \pm 1.1^{\mathrm{a}}$ & $10.34 \pm 1.7^{\mathrm{b}}$ \\
& 30 & $15.67 \pm 1.4^{\mathrm{a}}$ & $10.67 \pm 1.1^{\mathrm{b}}$ \\
& 40 & $17.67 \pm 1.3^{\mathrm{a}}$ & $15.67 \pm 1.5^{\mathrm{a}}$ \\
& 50 & $18.67 \pm 1.2^{\mathrm{a}}$ & $17.00 \pm 0.5^{\mathrm{a}}$ \\
& 10 & $12.00 \pm 0.6^{\mathrm{a}}$ & $10.34 \pm 1.8^{\mathrm{a}}$ \\
MFE & 20 & $15.34 \pm 1.5^{\mathrm{a}}$ & $12.34 \pm 1.1^{\mathrm{b}}$ \\
& 30 & $19.34 \pm 1.3^{\mathrm{a}}$ & $13.34 \pm 1.5^{\mathrm{b}}$ \\
& 40 & $19.67 \pm 1.7^{\mathrm{a}}$ & $16.67 \pm 1.9^{\mathrm{b}}$ \\
& 50 & $22.34 \pm 1.0^{\mathrm{a}}$ & $17.67 \pm 0.7^{\mathrm{b}}$ \\
\hline
\end{tabular}

\section{Antibacterial activity of the fruits extracts}

The antibacterial activity of Tamarindus indica fruits extracts against Escherichia coli and Shigella sp is presented in Table 3,4. The result showed that methanol extract is more effective with average zone of inhibition of $15.95 \mathrm{~mm}$ than aqueous extract with average zone of inhibition of $13.05 \mathrm{~mm}$. Based on the result, Escherichia coli is more sensitive to the extract than Shigella sp. The zone of inhibition shown by Ciprofloxacin $(25 \mathrm{mg} / \mathrm{ml})$ is 23 and $21 \mathrm{~mm}$ for Escherichia coli and Shigella sp respectively.

\section{Minimum inhibitory concentration (MIC)}

The minimum inhibitory Concentration of aqueous and methanol extract of leaves and fruits is represented in Table 5. The result showed dilutions of various concentrations of aqueous and methanol leaves and fruits extracts can inhibit the growth of the isolates. Lower MIC $(3.125 \mathrm{mg} / \mathrm{ml})$ was shown by methanol fruits extract than aqueous extract with $6.25 \mathrm{mg} / \mathrm{ml}$.

Table 5 Minimum inhibitory concentration (MIC) and MBC of the extracts Key: AFE, aqueous fruits extract; MFE, methanol fruits extract

\begin{tabular}{lllll}
\hline \multicolumn{5}{c}{ Leaves extract fruits extract } \\
\hline Isolates & $\begin{array}{l}\text { ALE } \\
(\mathbf{m g} / \mathbf{l})\end{array}$ & $\begin{array}{l}\text { MLE } \\
(\mathbf{m g} / \mathbf{m l})\end{array}$ & $\begin{array}{l}\text { AFE } \\
(\mathbf{m g} / \mathbf{m l})\end{array}$ & $\begin{array}{l}\text { MFE } \\
(\mathbf{m g} / \mathbf{m l})\end{array}$ \\
\hline $\begin{array}{l}\text { Escherichia } \\
\text { coli }\end{array}$ & 6.25 & 6.25 & 6.25 & 3.125 \\
Shigella sp & 25 & 6.25 & 6.25 & 3.125 \\
\hline
\end{tabular}

\section{Discussion}

The Phytochemical screening of the Tamarindus indica leaves and fruits extracts indicated the presence of alkaloid, tannin, saponin, glycoside, flavonoid, anthraquinone, reducing sugar, terpenoid, and phenols. The presence of the above phytochemicals in the plant parts was responsible for its antibacterial activity. Flavonoids have been shown to possess anti-inflammatory, anti-hepatotoxic and antimicrobial activities. ${ }^{16}$ Saponins are known to possess antibacterial activities $^{17,18}$ whilst tannins play an important role in wound healing and also possess some antimicrobial activities. According to this study, Alkaloid is also present in both the extracts. Alkaloid consists of large group of nitrogenous compound which are widely used as anticancer anesthetics and Central Nervous Stimulants. Alkaloids are known to play some metabolic roles and control development in living system. It also interferes with cell division, hence the presence of alkaloids in the Tamarindus indica leaves and fruits could account for their use as antimicrobial agents. The result of this study was inconformity with that of Sravanthi et al. ${ }^{19}$ who reported that Results of the phytochemical studies revealed the presence of tannins, saponins, alkaloids and tri terpenoidal saponins and the extracts were active against both gram positive and gram negative bacteria.

The antibacterial activity of the plant showed that Tamarindus indica leaves and fruits extracts demonstrated an antimicrobial effect against the test isolate with higher activity in methanol extract compared to aqueous extract. The methanolic extract had total zone of inhibition of $14.86 \mathrm{~mm}$ while $12.52 \mathrm{~mm}$ for $S$. typhi, while aqueous extract. This may be due to the better solubility of the active components in the organic solvent (methanol) than water which leads to better efficacy of the methanol extracts. It suggests that the active component is more soluble in ethanol than in the other solvents. However, Doughari et $\mathrm{al}^{8}{ }^{8}$ stated that the anti-microbial effect of the plant could be due to the bioactive compounds such as the phytochemicals constituent present in the plant. The results showed that the potency of the extracts on the test isolates had different hierarchy of susceptibility among the organisms. The findings of this study indicated that $E$. coli was more sensitive to the extracts with 
average zone of inhibition of $14.62 \mathrm{~mm}$ when compared to Shigella with average zone of inhibition of $11.47 \mathrm{~mm}$. The finding of this study supported the finding of Nwodo et al. ${ }^{20}$ who assessed the antibacterial activity of Tamarindus indica fruit pulp, stem bark and leaves extracts against some bacterial isolates. They found that the fruit pulp extracts exhibited a wide spectrum of activity; the cold water extract against $95.5 \%$ of the test bacterial strains; and the hot water and ethanolic extracts against $90.9 \%$ and $86.4 \%$, respectively. In contrast the cold water extract of the leaves and stem bark, each was active against $16.7 \%$; while the ethanolic extract of each was active against $75 \%$ of the test strains. The minimum inhibitory Concentration of aqueous and methanol extract of leaves and fruits showed dilutions of various concentrations of aqueous and methanol leaves and fruits extracts can inhibit the growth of the isolates at $3.125 \mathrm{mg} / \mathrm{ml}$ by methanol fruits extract and $6.25 \mathrm{mg} / \mathrm{ml}$ for aqueous extract.

Statistical analysis of the result revealed that the fruit extract is more effective than the leaves extract. The fruits extracts has an average zone of inhibition of $14.70 \mathrm{~mm}$ while leaves extract has an average zone of $11.39 \mathrm{~mm}$. There is considerable statistical difference on the activity of fruits and leaves extract tat $p<0.05$. Higher activity of fruits extracts can be attributed to higher number of phytochemical they contained when compared to leaves extracts. Nwodo et al. ${ }^{20}$ found that Tamarindus indica fruits extract has better efficacy than stem bark and leaves extracts, this support the finding of the present study.

\section{Conclusion}

Phytochemical screening of Tamarindus indica leaves and fruits extracts indicate the presence of presence of alkaloid, tannin, saponin, flavonoid and phenols, terpenoid, glycoside anthraquinone and reducing sugar. The antibacterial activity of the extracts against Escherichia coli and Shigella sp showed that both the extracts demonstrated an antimicrobial effect against the isolates. The Minimum inhibitory Concentration (MIC) of aqueous and methanol extract of the plant showed dilutions of various concentrations can inhibit growth the isolates. Findings from this work support the use of Tamarindus indica leaves and fruits extracts for medicinal purpose.

\section{Acknowledgements}

The authors wish to acknowledge to the staff of Potiskum Hospital for provision of Samples. Thanks to the technical staff of Biology Department, Yobe State University Damaturu for the use of laboratory facilities.

\section{Conflict of interest}

The authors declare that there is no conflict of interest.

\section{References}

1. www.kccil.us

2. Lai PK, Roy J. Antimicrobial and chemo preventive properties at herbs and spices. Curr Med Chem. 2004;11(11):1451-1460.

3. Kubmarawa D, Khan ME, Punah AM, et al. Phytochemical screening and antimicrobial efficacy of extracts of Khaya senegalensis against human pathogenic bacteria. Afric J Biotechnol. 2008;7(24):4563-4566.

4. Okeke IN, Lamikanra A, Edelman R. Socio-economic and behavioural factors leading to acquired bacterial resistance to antibiotics in developing countries. Emerg Infect Dis. 1999;5(1):18-27.

5. Khanzada SK, Shaikh WS, Kazi TG, et al. Chemical constituent of Tamarindus indica L medicinal plant in Sindi. Park J. 2008;10(4).

6. Joyeux M, Mortier F, Flurenti J. Sreeninng of antiradical, anti lipo proxident and hepato to protective effects of nine plants extracts used in Garribbean folk medicine phytother. 1995;2(4).

7. El-siddiq G, Prassad P, Ramana V, et al. Tamarindus indica. Southampton UK Center for Underutilized Crops. 2006.

8. Doughari JH. Antibacterial activity of Tamarindus indica linn. Trop $J$ Pharm. 2006;5(2):597-603.

9. Holt JG, Krieg NR, Sneath PH, et al. Bergey's Manual of Determinative Bacteriology. 9th edition. Williams and Wilkins: USA; 2002: 131:151156.

10. Chessbrough M. District laboratory practice in tropical countries. 2nd ed. Cambridge university press: USA; 2006: 80-85.

11. Ali M, Aminu F, Ibrahim IS. In-vitro Assessment of Antibacterial Activity and Phytochemical Screening of Vitex doniana on Clinical Isolate of Salmonella typhi. International Journal of Advanced Academic Research. 2016;3(1):9-16.

12. Okoli AS and Imegbu IU. Evaluation of attract of anthocleista dzalonensi, nauclea latitalia and uvaria atzali for activity against bacterial isolates from laces of non-gonocial urethritis. Journal of ethnolphamalogy. 2004;92(1):135-144.

13. Ali M, Yahaya A, Zage AU, et al. In-vitro Antibacterial Activity and Phytochemical Screening of Psidium guajava on Some Enteric Bacterial Isolates of Public Health Importance 2017. Journal of Advances in Medical and Pharmaceutical Sciences. 2017;12(3):1-7.

14. Kumar R, Sharma RJ, Bairwa K, et al. Pharmacological review on natural diarrhoea agents. Der pharma chemical. 2010;2(2):66-93.

15. Ahmed I, Beg AZ. Antimicrobial and phytochemical studies on 45 Indian Medicinal plants against multi-drug resistance human pathogens. $J$ Ethnopharmacol. 2001;74:113-123.

16. Madubunyi II. Antimicrobial Activities of the Constituents of Garcinia kola seeds. Intern J Pharmacog. 1995;33:232-237.

17. Gonzalez-Lamothe R, Mitchell G, Gattuso M, et al. Plant antimicrobial agents and their effects on plant and human pathogens. J Mol Sci. 2009; 10:3400-3419.

18. Cowan MM. Plants products as antimicrobial agents. Clin Microbiol Rev. 1999;12(4):564-582.

19. Sravanthi T, Kavita Waghray, Subba Rao D. Phytochemical screening and anti-microbial and anti-oxidant studies of dehydrated tender tamarind (Tamarindus indica) leaves. International Journal of Food Science and Nutrition. 2017;2(1):62-64

20. Nwodo UU, Obiiyeke GE, Chigor VN, et al. Assessment of Tamarindus indica extracts for Antibacterial Activity. Int J Mol Sci. 2011;12(10):63856396. 